\title{
Plasma carotenoids and diabetic retinopathy
}

\author{
Laima Brazionis $^{1 *}$, Kevin Rowley ${ }^{2}$, Catherine Itsiopoulos ${ }^{1}$ and Kerin O’Dea ${ }^{1}$ \\ ${ }^{1}$ Department of Medicine, University of Melbourne (St Vincent's Hospital), Melbourne, VIC 3065, Australia \\ ${ }^{2}$ Onemda VicHealth Koori Health Unit, Centre for Health and Society, School of Population Health, University of Melbourne, \\ Melbourne, VIC 3010, Australia
}

(Received 31 January 2008 - Revised 14 April 2008 - Accepted 1 May 2008 - First published online 13 June 2008)

Diabetic retinopathy increases with duration of diabetes and may be associated with carotenoid status. Carotenoids alter the pro-oxidation/antioxidation balance, and circulating levels depend largely on dietary intake. Lower levels have been reported in diabetes and age-related macular degeneration; however, little is known of the relationship between carotenoids and diabetic complications. Consequently, the purpose of the present study was to evaluate the relationship between plasma carotenoids and diabetic retinopathy. We assessed the carotenoid-retinopathy relationship in 111 individuals with type 2 diabetes in a community-based, cross-sectional study. We photodocumented retinal status and used HPLC to measure plasma carotenoid concentrations. Data for clinical and demographic variables and risk factors for diabetic retinopathy were obtained from $24 \mathrm{~h}$ urine and fasting blood samples, and an interviewer-assisted lifestyle questionnaire. We found that the combined lycopene and lutein/zeaxanthin (non-pro-vitamin A (non-PVA) carotenoid) concentration when compared with the pro-vitamin A (PVA) carotenoids ( $\alpha$-carotene, $\beta$-carotene and $\beta$-cryptoxanthin) was significantly lower in the retinopathy than non-retinopathy group (OR 1.2 (95\% CI $1.0,1.4) v$. $1.6(95 \%$ CI 1.4 1.7), respectively; $P=0.009)$. A higher non-PVA:PVA ratio also predicted a lower risk of diabetic retinopathy, after adjustment for potential confounders (OR 0.33 (95\% CI 0.12, 0.95); $P=0.039)$. Finally, a higher concentration of PVA carotenoids was associated with greater odds of diabetic retinopathy, after adjustment for risk factors $(P=0.049)$. We suggest synergies between carotenoids are implicated in diabetic retinopathy, independent of established risk factors. Importantly, our observations indicate dietary modulation of retinopathy risk may be possible by increasing intakes of lutein- and lycopene-rich foods.

Carotenoids: Diabetic retinopathy: Pro-vitamin A

Carotenoids demonstrate a vast array of biological activities, including vital roles in the eye, both functionally as precursors to retinol in the visual pathway (pro-vitamin A (PVA) carotenoids) and structurally as macular pigments. The major PVA carotenoids in plasma are $\alpha$-carotene, $\beta$-carotene and $\beta$-cryptoxanthin. Of these, only $\beta$-carotene is found in ocular tissues $^{(1)}$.

In contrast, lutein/zeaxanthin and lycopene are the major non-PVA carotenoids, i.e. are not retinol precursors, and both are present in ocular tissues at high concentrations. Lutein and zeaxanthin comprise the macular pigments, essential for normal vision and for the protection of photoreceptors from phototoxic blue light, while lycopene is present in high concentrations in the human ciliary body and retinal pigment epithelium/choroid ${ }^{(2)}$.

Plasma carotenoid concentrations have been linked to numerous conditions ${ }^{(3-6)}$ including the major blinding conditions - age-related macular degeneration ${ }^{(7,8)}$ and cataracts ${ }^{(9)}$. To date, the relationship between the major carotenoids and diabetic retinopathy has not been evaluated (Table 1). Consequently, we undertook to investigate the association between plasma carotenoids and diabetic retinopathy.

\section{Subjects and methods \\ Diabetes status}

Self-reported diabetes status was confirmed biochemically, according to the WHO diagnostic criteria for the classification of diabetes ${ }^{(10)}$.

\section{Subject selection}

In order to broaden the range of dietary intakes and lifestyle exposures, we sourced subjects from the Melbourne Collaborative Cohort Study (MCCS), a community-based prospective cohort of 41528 male and female volunteers, aged 40-69 years at baseline (1989-94), recruited from the electoral roll, and ethnic radio, clubs, and churches ${ }^{(11)}$. We invited 157 men with type 2 diabetes and not taking carotenoid supplements to participate in the present study. Of these, we excluded three (two men with type 1 diabetes and one man with ungradeable photographs). Of the eligible subjects ( $n 154), 72 \%$ ( $n 111)$ participated in the study. Ethics approval was obtained from the MCCS scientific committee and Deakin and Monash Universities (Melbourne, Australia), and written informed consent was obtained from every participant. 
Table 1. Diabetes-related studies of plasma concentrations of major carotenoids ${ }^{(5,6,24,25,35,37-54)}$

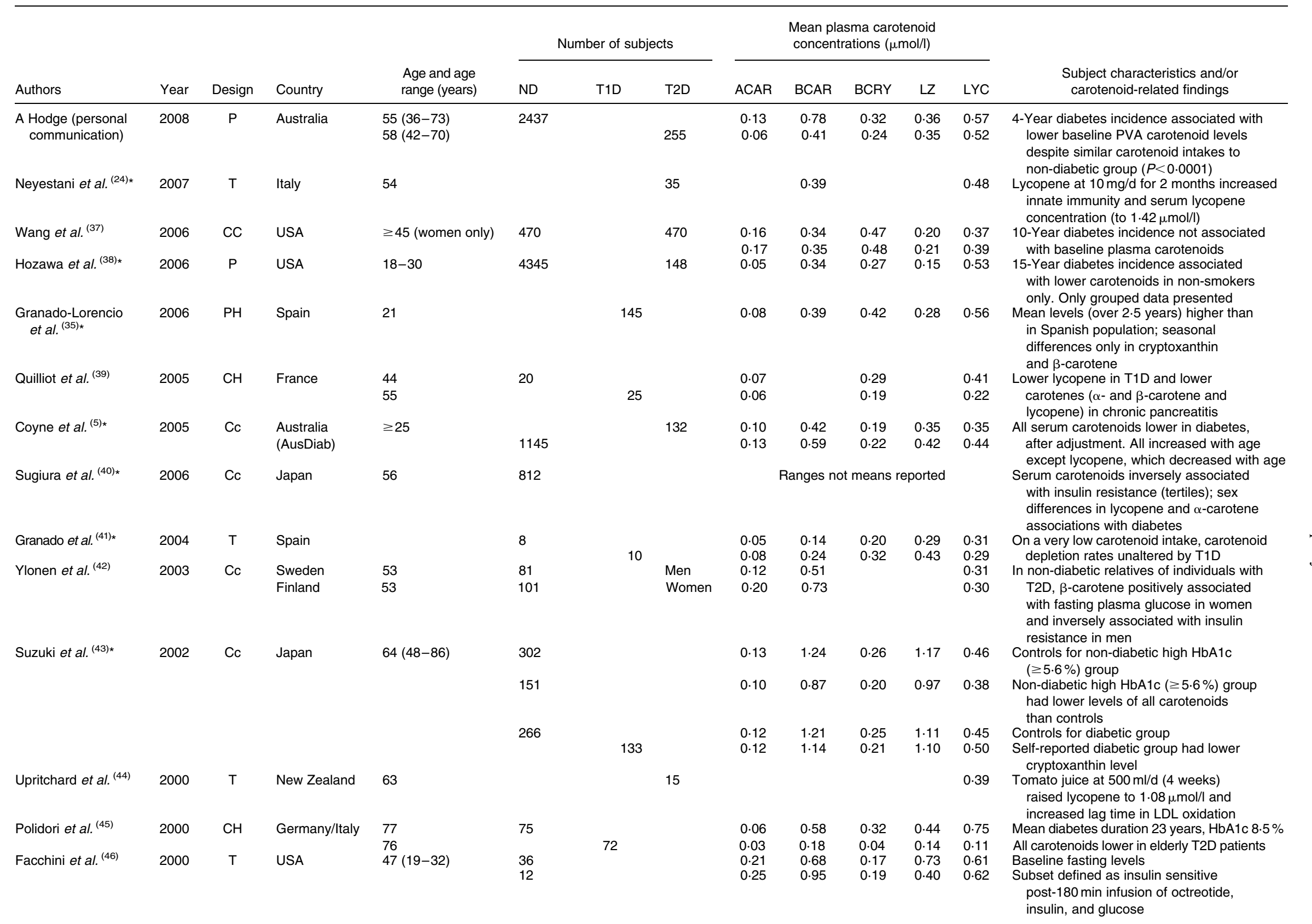


NS British Journal of Nutrition

\begin{tabular}{|c|c|c|c|c|c|c|c|c|c|c|c|c|c|}
\hline \multirow[b]{2}{*}{ Authors } & \multirow[b]{2}{*}{ Year } & \multirow[b]{2}{*}{ Design } & \multirow[b]{2}{*}{ Country } & \multirow{2}{*}{$\begin{array}{l}\text { Age and age } \\
\text { range (years) }\end{array}$} & \multicolumn{3}{|c|}{ Number of subjects } & \multicolumn{5}{|c|}{$\begin{array}{l}\text { Mean plasma carotenoid } \\
\text { concentrations }(\mu \mathrm{mol} / \mathrm{l})\end{array}$} & \multirow{2}{*}{$\begin{array}{l}\text { Subject characteristics and/or } \\
\text { carotenoid-related findings }\end{array}$} \\
\hline & & & & & ND & T1D & $\mathrm{T} 2 \mathrm{D}$ & ACAR & BCAR & BCRY & LZ & LYC & \\
\hline Levy et al. ${ }^{(47)}$ & 2000 & $\mathrm{~T}$ & Israel & 52 & 12 & & 20 & 0.08 & 0.34 & 0.15 & 0.30 & 0.55 & $\begin{array}{l}\text { Subset defined as insulin resistant after } \\
\text { same infusion; lutein, } \alpha \text {-and } \beta \text {-carotene } \\
\text { lower in insulin-resistant subset } \\
\beta \text {-Carotene at } 60 \mathrm{mg} / \mathrm{d}(\mathrm{3} \text { weeks) increased } \\
\text { plasma levels } 2 \cdot 3-\text {-fold to } 1.70 \mu \mathrm{mol} / / \\
\text { and lag time in LDL oxidation; diabetic } \\
\text { LDL had half the carotenoid }\end{array}$ \\
\hline \multirow[t]{3}{*}{ Ford et al. ${ }^{(6) *} \dagger$} & 1999 & $\mathrm{Cc}$ & USA & $\begin{array}{l}54(47-74) \\
56(47-74)\end{array}$ & $\begin{array}{l}959 \\
262\end{array}$ & & & $\begin{array}{l}0.10 \\
0.09\end{array}$ & $\begin{array}{l}0.43 \\
0.34\end{array}$ & $\begin{array}{l}0.16 \\
0.18\end{array}$ & $\begin{array}{l}0.41 \\
0.43\end{array}$ & $\begin{array}{l}0.42 \\
0.39\end{array}$ & $\begin{array}{l}\text { Normal glucose tolerance } \\
\text { Impaired glucose tolerance; lower } \\
\beta \text {-carotene levels than normal glucose } \\
\text { tolerance group }\end{array}$ \\
\hline & & & & $60(47-74)$ & & & 139 & 0.07 & 0.26 & 0.12 & 0.38 & 0.38 & $\begin{array}{l}\text { Newly diagnosed T2D; } P \text { (linear trend } \\
\text { across first three groups) significant for } \\
\beta \text {-carotene and lycopene }\end{array}$ \\
\hline & & & & $61(47-74)$ & & & 203 & 0.09 & 0.41 & 0.18 & 0.57 & 0.45 & $\begin{array}{l}\text { Previously diagnosed T2D not associated } \\
\text { with carotenoids }\end{array}$ \\
\hline Abahusain et al. ${ }^{(48) *}$ & 1999 & $\mathrm{CC}$ & Saudi Arabia & $\begin{array}{l}50(28-74) \\
49(27-75)\end{array}$ & 140 & & 105 & $\begin{array}{l}0.08 \\
0.08\end{array}$ & $\begin{array}{l}0.28 \\
0.39\end{array}$ & & & & Serum $\beta$-carotene lower in T2D \\
\hline \multirow[t]{2}{*}{ Anderson et al. ${ }^{(49) \star}$} & 1999 & $\mathrm{~T}$ & USA & 47 & 21 & & & & 0.05 & & & & $\begin{array}{l}\text { Control group was not well matched for age } \\
\text { and TAG }\end{array}$ \\
\hline & & & & 63 & & & 16 & & $0 \cdot 10$ & & & & $\begin{array}{l}\beta \text {-Carotene at } 24 \mathrm{mg} / \mathrm{d} \text { ( } 24 \text { weeks) doubled } \\
\text { serum } \beta \text {-carotene concentration }\end{array}$ \\
\hline Reunanen et al. ${ }^{(50) *}$ & 1998 & $\mathrm{Cc}$ & Finland & $60(15-99)$ & 201 & & 106 & & $\begin{array}{l}1.6 \\
1.9\end{array}$ & & & & $\begin{array}{l}\beta \text {-Carotene lower in diabetes, but lifestyle } \\
\text { factors important confounders of } \\
\beta \text {-carotene/diabetes link }\end{array}$ \\
\hline \multirow[t]{5}{*}{ Granado et al. ${ }^{(25) *}$} & 1998 & $\mathrm{CH}$ & Spain & & & 54 & $\begin{array}{l}\text { Men } \\
\text { Women }\end{array}$ & $\begin{array}{l}0.06 \\
0.09\end{array}$ & $\begin{array}{l}1.9 \\
0.31 \\
0.44\end{array}$ & $\begin{array}{l}0.55 \\
0.56\end{array}$ & $\begin{array}{l}0.25 \\
0.28\end{array}$ & $\begin{array}{l}0.42 \\
0.40\end{array}$ & T1D not associated with lower carotenoid \\
\hline & & & & & 214 & & Men & 0.05 & 0.22 & 0.34 & 0.24 & 0.38 & \\
\hline & & & & & relatives & & Women & 0.07 & 0.32 & 0.47 & 0.26 & 0.39 & \\
\hline & & & & & & & Men & 0.08 & 0.27 & 0.39 & 0.31 & 0.41 & \\
\hline & & & & & unrelated & & Women & 0.09 & 0.38 & 0.60 & 0.31 & 0.45 & \\
\hline \multirow[t]{3}{*}{ Olmedilla et al. ${ }^{(51) \star} \ddagger$} & 1997 & $\mathrm{CC}$ & Spain & $32(5-79)$ & $\begin{array}{l}210 \\
240\end{array}$ & & Men & $\begin{array}{l}0.05 \\
0.06\end{array}$ & 0.22 & 0.28 & 0.25 & $\begin{array}{l}0.35 \\
0.36\end{array}$ & \\
\hline & & & & $27(13-84)$ & & & 60 & 0.06 & $\begin{array}{l}0.28 \\
0.28\end{array}$ & 0.34 & 0.23 & 0.42 & Dietary intake does not predict serum \\
\hline & & & & & & Women & 63 & 0.07 & 0.36 & 0.44 & 0.25 & 0.42 & lycopene level in T2D \\
\hline Krill et al. ${ }^{(52) *}$ & 1997 & $\mathrm{Cc}$ & USA & Not reported & 27 & 13 & & & & reported & & & $\begin{array}{l}\text { Total serum carotenoids in T1D } v \text {. } \\
\text { non-diabetic relatives were } 1.12\end{array}$ \\
\hline Rock et al. ${ }^{(53) \star}$ & 1997 & $\mathrm{CH}$ & USA & $57(21-84)$ & & & & & & reported & & & $\begin{array}{l}\text { V. } 1.28 \mu \mathrm{mol} / \mathrm{l}, \text { respectively (NS) } \\
\text { Plasma } \beta \text {-carotene lower in diabetic than } \\
\text { non-diabetic ESRD (data not shown) }\end{array}$ \\
\hline O'Brien et al. ${ }^{(54) *}$ & 1996 & $\mathrm{CH}$ & Australia & $40(21-69)$ & & 121 & & & 0.48 & & & & $\begin{array}{l}\text { No association between } \beta \text {-carotene } \\
\text { and albuminuria (ACR }>3 \mathrm{mg} / \mathrm{mmol} \text { ) }\end{array}$ \\
\hline
\end{tabular}

ND, non-diabetic; T1D, type 1 diabetes; T2D, type 2 diabetes; ACAR, $\alpha$-carotene; BCAR, $\beta$-carotene; BCRY, $\beta$-cryptoxanthin; LZ, lutein + zeaxanthin; LYC, lycopene; P, prospective; PVA, pro-vitamin A; T, controlled clinical trial; $\mathrm{CC}$, case-contro; $\mathrm{H}$, hospital-based; C, cross-sectional; c, community-based; ESRD, end-stage renal disease; ACR, albumin:creatinine ratio (as indicator of glomerular dysfunction) Serum not plasma levels.

† Age-adjusted data. 


\section{Diabetic retinopathy}

We used a mydriatic retinal fundus camera (Kowa FX-500S, Japan) to photodocument retinal status. Diabetic retinopathy grading was based on the EURODIAB protocol (validated against the Airlie House classification) in which the overall grading was that of the worse eye and diabetic retinopathy was defined as more than one microaneurysm and/or haemorrhage ${ }^{(12)}$. A medical retina specialist, masked to all other participant information, graded the slides on two separate occasions in order to assess internal validity. Agreement between gradings was excellent ( $\kappa$ value of 0.986 ).

\section{Clinical measures and retinopathy risk factors}

Systolic and diastolic blood pressure was recorded using a Dinamap XL portable automated adult vital signs monitor (model 9300; Critikon, FL, USA). Blood pressure was recorded as the average of the last two of three consecutive readings, obtained from the right arm of seated subjects at $1 \mathrm{~min}$ intervals after a $10 \mathrm{~min}$ rest period. Weight was measured to within $0.1 \mathrm{~kg}$, using digital electronic scales (UC-300; A.N.D, Tokyo, Japan), before breakfast and following a $12 \mathrm{~h}$ fast, with subjects wearing light clothing and no shoes. Height was measured to within $0.1 \mathrm{~cm}$ using a wall-mounted stadiometer (Harpenden; Holtain Limited, Crymych, UK). BMI was calculated as weight $(\mathrm{kg}) / \mathrm{height}(\mathrm{m})^{2}$. A 'current smoker' was defined as a subject who smoked at least seven cigarettes per week at the time of completing the questionnaire.

\section{Plasma biochemistry}

A fasting blood sample was drawn between 08.00 and 10.00 hours on the morning of the clinical evaluation. Carotenoids were analysed in plasma separated from blood treated with EDTA as anticoagulant and stored at $-80^{\circ} \mathrm{C}$ and protected from light until analysed. Extraction was as follows: $200 \mu \mathrm{l}$ of plasma and $200 \mu \mathrm{l}$ of $95 \%$ ethanol (containing $\alpha$-tocopheryl acetate $(200 \mathrm{ng} / \mathrm{ml})$ and retinyl acetate $(750 \mathrm{ng} / \mathrm{ml})$ as internal standards) were placed in $13 \times 100 \mathrm{~mm}$ borosilicate tubes (Laboratory Supply, Melbourne, VIC, Australia). Hexane $(1 \mathrm{ml})$ containing $0.01 \%$ butylated hydroxytoluene was added. The different phases were then separated by centrifugation at $2000 \mathrm{~g}$ for $10 \mathrm{~min}$. The organic phase was removed by evaporation under $\mathrm{N}_{2}$. The residue was reconstituted in $30 \mu \mathrm{l}$ chloroform before the addition of $70 \mu \mathrm{l}$ acetonitrile-methanol $(1: 1, \mathrm{v} / \mathrm{v})$ and transferred to light-protected vials maintained at $40^{\circ} \mathrm{C}$.

A modified HPLC method, developed and reported elsewhere by $\mathrm{Su}$ et al. ${ }^{(13)}$ was used to analyse the prepared samples. Calibration and peak identification for the carotenes were achieved by the use of pure standards obtained from Sigma (St Louis, MO, USA), while calibration and peak identification for lutein/zeaxanthin and $\beta$-cryptoxanthin were achieved by the use of pure standards obtained from Hoffman La Roche (Basel, Switzerland). The inter-batch CV was $<10 \%$ for all analytes except lycopene for which the CV was $12 \%$.

Plasma glucose concentrations were analysed using an automatic analyser (Hitachi model 705, Tokyo, Japan) and a commercial enzymic kit (Boehringer Mannheim GmbH Diagnostica, Mannheim, Germany) by the glucose oxidase method. Plasma cholesterol and TAG concentrations were analysed with an automatic analyser (Hitachi model 705, Tokyo, Japan) using a commercial enzymic kit (Boehringer Mannheim GmbH Diagnostica, Mannheim, Germany).

\section{Urinary biochemistry}

Urinary albumin concentration was measured using immunonephelometry (Kallestadt QM300 or Beckman 360 Array nephelometers; inter-assay $\mathrm{CV}$ was 3-5\%). Urinary creatinine concentration was measured using an alkaline picrate method (Olympus AU800 autoanalyser; inter-assay CV was $2 \%)$. The urinary albumin:creatinine ratio was then calculated as albumin $(\mathrm{mg}) /$ creatinine $(\mathrm{mmol})$.

\section{Statistical analyses}

We used SPSS version 13 for Windows (SPSS Inc., Chicago, IL, USA) software to perform the statistical analyses. The data were cross-sectional observations. Descriptive statistics for the exposure and outcome variables were obtained, and variables with distributions that were not normally distributed were logtransformed before analysis. Associations between categorical variables were analysed using $\chi^{2}$ tests.

Initially, variables assessed in univariate analyses, including known risk factors for diabetic retinopathy, were modelled using binomial logistic regression analysis to determine the best clinical predictors of diabetic retinopathy. Plasma carotenoid concentrations were then added to subsequent models that controlled for the major risk factors for diabetic retinopathy. The fit of each model was tested and the Nagelkerke $R^{2}$ approximation was compared. $P<0.05$ was considered statistically significant.

\section{Results}

The mean age of the participants was 64 (range 44-77) years. The clinical and demographic characteristics of the participants, according to retinopathy status, are shown in Table 2 . Diabetic retinopathy was significantly associated with established risk factors, i.e. duration of diabetes, $\mathrm{HbA1c}$, use of hypoglycaemic medication, and the albumin excretion rate. A longer duration of diabetes was, however, the only independent predictor of diabetic retinopathy, as demonstrated by multivariate modelling of these factors (data not shown). Mean plasma cholesterol and TAG concentrations were in the normal range and not significantly different between retinopathy and non-retinopathy cases. Consequently, subsequent analyses were not adjusted for cholesterol and TAG concentrations.

The observed mean concentration of each carotenoid for both retinopathy and non-retinopathy cases was within the range of means reported in other diabetic populations (Table 1). The observed $\alpha$-carotene concentrations were at the higher end of values reported in other diabetic populations and were associated with diabetic retinopathy. Conversely, lycopene, a non-PVA carotenoid, demonstrated a trend to lower levels in the retinopathy group (Table 2). In addition, a higher plasma non-PVA:PVA carotenoid ratio was inversely 
Table 2. Characteristics of diabetic subjects according to retinopathy status (Prevalence rates or mean values and $95 \%$ confidence intervals)

\begin{tabular}{|c|c|c|c|c|c|}
\hline \multirow[b]{2}{*}{ Characteristic } & \multicolumn{2}{|c|}{ Retinopathy absent ( $n$ 78) } & \multicolumn{2}{|c|}{ Retinopathy present ( $n$ 33) } & \multirow[b]{2}{*}{$P$} \\
\hline & Mean & $95 \% \mathrm{Cl}$ & Mean & $95 \% \mathrm{Cl}$ & \\
\hline Age (years) & 63 & 62,65 & 65 & 61,68 & 0.504 \\
\hline Fasting glucose $(\mathrm{mmol} / \mathrm{l})$ & $10 \cdot 1$ & $9 \cdot 6,10 \cdot 7$ & $10 \cdot 1$ & $9 \cdot 2,11.0$ & 0.895 \\
\hline $\mathrm{HbA} 1 \mathrm{c}(\%)$ & 7.9 & $7 \cdot 6,8 \cdot 3$ & $8 \cdot 8$ & $8 \cdot 2,9 \cdot 4$ & 0.018 \\
\hline Diabetes duration (years) & 9 & 7,10 & 16 & 12,19 & $<0.0001$ \\
\hline Hypoglycaemic medication (\%) & \multicolumn{2}{|c|}{63} & \multicolumn{2}{|c|}{88} & $0.009^{*}$ \\
\hline $\mathrm{BMI}\left(\mathrm{kg} / \mathrm{m}^{2}\right)$ & 29 & 28,30 & 28 & 27,30 & 0.228 \\
\hline Systolic blood pressure (mmHg) & 142 & 137,146 & 149 & 141,156 & 0.114 \\
\hline Diastolic blood pressure $(\mathrm{mmHg})$ & 75 & 73,77 & 74 & 71,77 & 0.638 \\
\hline Current smoker (\%) & \multicolumn{2}{|c|}{13} & \multicolumn{2}{|c|}{6} & $0.311^{*}$ \\
\hline Urinary albumin excretion rate ( $\mu \mathrm{g} / \mathrm{min})$ & 47 & 22,71 & 174 & 46,302 & 0.008 \\
\hline Total cholesterol $(\mathrm{mmol} / \mathrm{l})$ & $5 \cdot 3$ & $5 \cdot 0,5 \cdot 5$ & $5 \cdot 0$ & $4 \cdot 7,5 \cdot 3$ & 0.176 \\
\hline HDL-cholesterol (mmol/l/) & 1.1 & $1 \cdot 0,1 \cdot 2$ & 1.2 & $1 \cdot 1,1 \cdot 3$ & 0.375 \\
\hline $\mathrm{TAG}(\mathrm{mmol} / \mathrm{l})$ & $2 \cdot 0$ & $1 \cdot 6,2 \cdot 3$ & 1.7 & $1.4,1.9$ & 0.280 \\
\hline$\alpha$-Carotene $(\mu \mathrm{mol} / \mathrm{l})$ & 0.08 & $0.07,0.10$ & 0.12 & $0.09,0.16$ & 0.029 \\
\hline$\beta$-Carotene $(\mu \mathrm{mol} / \mathrm{l})$ & 0.37 & $0.29,0.44$ & 0.40 & $0.29,0.51$ & 0.576 \\
\hline Cryptoxanthin $(\mu \mathrm{mol} / \mathrm{l})$ & 0.21 & $0 \cdot 16,0.26$ & 0.21 & $0.16,0.26$ & 0.940 \\
\hline Lutein + zeaxanthin $(\mu \mathrm{mol} / \mathrm{l})$ & 0.36 & $0.30,0.41$ & 0.34 & $0.27,0.42$ & 0.736 \\
\hline Lycopene $(\mu \mathrm{mol} / \mathrm{l})$ & 0.45 & $0.39,0.51$ & 0.36 & $0.30,0.42$ & 0.079 \\
\hline
\end{tabular}

* Pearson $\chi^{2} P$ values.

associated with diabetic retinopathy $(1.6(95 \%$ CI $1.4,1.7) v$. 1.2 (95\% CI $1.0,1.4)$, respectively; $P=0.009$ ).

In multivariate modelling of carotenoids as predictors of diabetic retinopathy (Table 3), the odds of diabetic retinopathy increased with higher plasma concentrations of the PVA carotenoids (model 1). The ratio of non-PVA:PVA carotenoid concentrations was the best carotenoid-related predictor of diabetic retinopathy. A higher combined plasma concentration of lycopene and lutein/zeaxanthin was associated with significantly lower odds of diabetic retinopathy, after adjusting for potential confounding by retinopathy risk factors (model 2 ).

\section{Discussion}

To date, little is known of the role of carotenoids in diabetes and its complications. Consequently, costly intervention studies of the potential impact of carotenoids on diabetic retinopathy are not yet justifiable, despite evidence of a biologically plausible mechanism, oxidative stress. The present cross-sectional study evaluated the association between diabetic retinopathy and the concentrations of major plasma carotenoids, which in turn are largely, but not exclusively, dependent on dietary intake ${ }^{(14)}$. Our key finding supports a protective role for a higher combined lutein/zeaxanthin and lycopene concentration against diabetic retinopathy, after adjustment for potential confounders. There are important distinctions between lutein/zeaxanthin and lycopene (non-PVA carotenoids) and the other three major (PVA) carotenoids in humans. Lutein/zeaxanthin and lycopene are absorbed intact, unlike $\alpha$ - and $\beta$-carotene and $\beta$-cryptoxanthin, which can be cleaved to form retinol and, before absorption, are partly metabolised to vitamin A in the intestinal mucosa ${ }^{(15)}$. Whether competitive inhibition influences PVA carotenoid cleavage at particular intake levels is not well understood. Furthermore, $\beta$-carotene is ubiquitous and food sources of various carotenoid combinations differ: lycopene and $\beta$-carotene, but not $\alpha$-carotene, are present in tomatoes, while carrots and pumpkin are good sources of $\alpha$-carotene and $\beta$-carotene, but not lycopene, and cryptoxanthin is primarily found in citrus fruits.

Apart from the key structural role of lutein and zeaxanthin as the macular pigments in the eye, evidence is emerging of a wider role for lutein in chronic disease prevention ${ }^{(16)}$. In particular,

Table 3. Adjusted regression models of plasma carotenoids $(\mu \mathrm{mol} / \mathrm{l})$ as predictors of diabetic retinopathy*

\begin{tabular}{|c|c|c|c|c|c|c|c|}
\hline Model & $R^{2}$ & Independent variable & $\mathrm{B}$ & SE & $\operatorname{Exp}(B)$ & $95 \% \mathrm{Cl}$ for $\operatorname{Exp}(\mathrm{B})$ & $P$ \\
\hline \multirow[t]{6}{*}{1} & \multirow[t]{6}{*}{0.32} & Duration of diabetes (years) & 0.11 & 0.04 & $1 \cdot 12$ & $1.03,1.20$ & 0.004 \\
\hline & & $\mathrm{HbA1c}(\%)$ & 0.17 & $0 \cdot 16$ & $1 \cdot 19$ & $0.87,1.63$ & 0.280 \\
\hline & & Hypoglycaemic medication(s) (\%) & 0.37 & 0.76 & 1.45 & $0.33,6.40$ & 0.622 \\
\hline & & Albumin excretion rate $(\mu \mathrm{g} / \mathrm{min})$ & 0.00 & 0.00 & 1.00 & $1.00,1.01$ & 0.105 \\
\hline & & PVA carotenoids $(\mu \mathrm{mol} / \mathrm{l})$ & 1.09 & 0.55 & 2.97 & $1.00,8.79$ & 0.049 \\
\hline & & Non-PVA carotenoids ( $\mu \mathrm{mol} / \mathrm{l})$ & $-1 \cdot 16$ & 0.66 & 0.31 & $0.09,1.14$ & 0.077 \\
\hline \multirow[t]{5}{*}{2} & \multirow[t]{5}{*}{0.34} & Duration of diabetes (years) & 0.11 & 0.04 & $1 \cdot 12$ & $1 \cdot 04,1 \cdot 20$ & 0.004 \\
\hline & & HbA1c (\%) & 0.17 & $0 \cdot 16$ & $1 \cdot 19$ & $0.87,1.63$ & 0.282 \\
\hline & & Hypoglycaemic medication(s) (\%) & 0.40 & 0.74 & 1.49 & $0.35,6.33$ & 0.592 \\
\hline & & Albumin excretion rate ( $\mu \mathrm{g} / \mathrm{min})$ & 0.00 & 0.00 & 1.00 & $1.00,1.01$ & 0.107 \\
\hline & & Non-PVA:PVA ratio & $-1 \cdot 11$ & 0.54 & 0.33 & $0.12,0.95$ & 0.039 \\
\hline
\end{tabular}

PVA, pro-vitamin A carotenoids ( $\alpha-+\beta$-carotene + cryptoxanthin); non-PVA, non-pro-vitamin A carotenoids (lutein/zeaxanthin + lycopene).

${ }^{*}$ Carotenoid and albumin excretion rate data are log-transformed. 
lutein has been shown to attenuate oxidative stress in experimental models of early diabetic retinopathy ${ }^{(17,18)}$. A role for lycopene in ocular health is also plausible; lycopene is present in high concentrations in human ocular tissues ${ }^{(19)}$, is the most potent carotenoid quencher of singlet oxygen ${ }^{(20)}$, and has other important functions. In vitro studies have shown that lycopene can inhibit proliferation and induce differentiation of human blood cells, activate genes involved in cell-to-cell communication, and modulate lipoxygenase activity and therefore inflammation and immune function ${ }^{(21)}$. According to in vitro studies and animal research ${ }^{(9)}$, lycopene can attenuate oxidative stress-induced experimental cataract in rat lenses via an antioxidant mechanism involving restoration of levels of endogenous antioxidant enzymes, such as superoxide dismutase and catalase. In one study, lycopene-treated diabetic rabbits demonstrated an increase in antioxidant activity in ocular capillaries and lacrimal fluid ${ }^{(22)}$. Low plasma lycopene concentrations have been associated with the very early stages of vascular disease in humans ${ }^{(23)}$, indicating that lycopene contributes to the expression of the disease. Furthermore, lycopene bioavailability is impaired in older individuals ${ }^{(7)}$. In contrast, $\beta$-carotene bioavailability is maintained with age, as is the intestinal conversion of PVA carotenoids to vitamin A. Recently, a double-blind placebo-controlled clinical trial found a physiological dose of lycopene for 2 months suppressed oxidative stress and enhanced innate immunity in individuals with type 2 diabetes $^{(24)}$.

We also observed an association between retinopathy and plasma PVA carotenoid concentrations. This finding is consistent with one study in which individuals with type 1 diabetes had higher plasma concentrations of PVA (but not non-PVA) carotenoids and lower levels of retinol than their first-degree relatives ${ }^{(25)}$, suggesting impaired bioconversion of carotenoids to retinol. Diabetes may also promote higher levels of PVA carotenoids via another mechanism, such as down-regulation of the bioconversion of PVA carotenoids to retinol, secondary to a nephropathy-induced accumulation of retinol, levels of which are homeostatically controlled ${ }^{(26,27)}$ and can be higher in renal disease ${ }^{(28,29)}$ and diabetes ${ }^{(30)}$. Importantly, our observation does not demonstrate a negative role of dietary PVA carotenoids. Prospective studies are needed to further evaluate the association between retinopathy and plasma PVA carotenoid concentrations.

Different food sources and intake levels may in part explain the large variation in the ratio of circulating $\alpha$-carotene: $\beta$-carotene reported in previous studies (Table 1). In addition, previous studies point to a complex interplay between carotenoids: non-PVA carotenoids (lutein/zeaxanthin and lycopene) can diminish PVA carotenoid bioavailability. Moreover, synergies have been demonstrated between non-PVA carotenoids $^{(31)}$, and competitive inhibition has been demonstrated between carotenoids, for example, for incorporation into chylomicrons ${ }^{(32-34)}$. It is also noteworthy that while carotenoid levels reflect relatively recent intake, evidence suggests that most individuals maintain relatively consistent eating patterns over time, with seasonal fluctuations affecting only cryptoxanthin and $\beta$-carotene levels ${ }^{(35)}$.

The main limitation of the present study is its observational nature. The lack of temporal direction prevents us from inferring causality. Consequently, prospective studies of diabetic retinopathy are needed to determine whether over time a higher combined plasma concentration of lutein/zeaxanthin and lycopene and/or a higher plasma non-PVA:PVA carotenoid ratio can reduce the risk of diabetic retinopathy. Residual confounding may have played a role in our observations, although sex, a key determinant of plasma carotenoid levels, was not a confounder in the present study as we selected only men with type 2 diabetes. However, the interaction between different food components may have confounded the present results. Furthermore, plasma carotenoids may be a marker for any of the many non-nutrient food components in vegetables and fruits ${ }^{(36)}$. Finally, although we used a validated protocol for retinal evaluation, our assessment of retinopathy may have underestimated diabetic maculopathy.

In conclusion, synergies between plasma carotenoids seem to be implicated in diabetic retinopathy, independent of established risk factors. In general, the present study provides additional data concerning the importance of carotenoid-rich foods for health maintenance and gives strength to the recommendation of increasing consumption of lutein- and lycopene-rich foods.

\section{Acknowledgements}

The present study would not have been possible without the MCCS and the infrastructure support provided by the Cancer Council Victoria. The National Health and Medical Research Council of Australia part-funded the present study (project no. 124317), which represents the collaboration of and contribution by many.

L. B. contributed to the design, data collection, data analyses, and the writing and revision of the manuscript. K. R. contributed to the design, data collection, and revision of the manuscript. C. I. contributed to the design, data collection, data analyses, and revision of the manuscript. K. O'D. contributed to the design and revision of the manuscript. No conflicts of interest exist.

\section{References}

1. Krinsky NI \& Johnson EJ (2005) Carotenoid actions and their relation to health and disease. Mol Aspects Med 26, 459-516.

2. Khachik F, Carvalho L, Bernstein PS, Muir GJ, Zhao DY \& Katz NB (2002) Chemistry, distribution, and metabolism of tomato carotenoids and their impact on human health. Exp Biol Med (Maywood) 227, 845-851.

3. Voutilainen S, Nurmi T, Mursu J \& Rissanen TH (2006) Carotenoids and cardiovascular health. Am J Clin Nutr 83, 1265-1271.

4. Ito Y, Kurata M, Hioki R, Suzuki K, Ochiai J \& Aoki K (2005) Cancer mortality and serum levels of carotenoids, retinol, and tocopherol: a population-based follow-up study of inhabitants of a rural area of Japan. Asian Pac J Cancer Prev 6, 10-15.

5. Coyne T, Ibiebele TI, Baade PD, Dobson A, McClintock C, Dunn S, Leonard D \& Shaw J (2005) Diabetes mellitus and serum carotenoids: findings of a population-based study in Queensland, Australia. Am J Clin Nutr 82, 685-693.

6. Ford ES, Will JC, Bowman BA \& Narayan KM (1999) Diabetes mellitus and serum carotenoids: findings from the Third National Health and Nutrition Examination Survey. Am J Epidemiol 149, 168-176.

7. Cardinault N, Abalain JH, Sairafi B, Coudray C, Grolier P, Rambeau M, Carre JL, Mazur A \& Rock E (2005) Lycopene but not lutein nor zeaxanthin decreases in serum and 
lipoproteins in age-related macular degeneration patients. Clin Chim Acta 357, 34-42.

8. Nilsson SE, Sundelin SP, Wihlmark U \& Brunk UT (2003) Aging of cultured retinal pigment epithelial cells: oxidative reactions, lipofuscin formation and blue light damage. Doc Ophthalmol 106, 13-16.

9. Gupta SK, Trivedi D, Srivastava S, Joshi S, Halder N \& Verma SD (2003) Lycopene attenuates oxidative stress induced experimental cataract development: an in vitro and in vivo study. Nutrition 19, 794-799.

10. World Health Organization (1999) World Health Organization: Diabetes Mellitus: Report of a WHO Study Group. Geneva: WHO.

11. Giles G (1990) The Melbourne study of diet and cancer. Proc Nutr Soc Aust 15, 61-68.

12. Aldington SJ, Kohner EM, Meuer S, Klein R \& Sjolie AK (1995) Methodology for retinal photography and assessment of diabetic retinopathy: the EURODIAB IDDM complications study. Diabetologia 38, 437-444.

13. Su Q, Rowley K \& O'Dea K (1999) Stability of individual carotenoids, retinol and tocopherols in human plasma during exposure to light and after extraction. J Chromatogr B Biomed Sci Appl 729, 191-198.

14. Coyne T, Ibiebele TI, McNaughton S, Rutishauser IH, O'Dea K, Hodge AM, McClintock C, Findlay MG \& Lee A (2005) Evaluation of brief dietary questions to estimate vegetable and fruit consumption - using serum carotenoids and red-cell folate. Public Health Nutr 8, 298-308.

15. Parker RS (1997) Bioavailability of carotenoids. Eur J Clin Nutr 51, Suppl. 1, S86-S90.

16. Ribaya-Mercado JD \& Blumberg JB (2004) Lutein and zeaxanthin and their potential roles in disease prevention. $J \mathrm{Am}$ Coll Nutr 23, Suppl. 6, 567S-587S.

17. Muriach M, Bosch-Morell F, Alexander G, Blomhoff R, Barcia J, Arnal E, Almansa I, Romero FJ \& Miranda M (2006) Lutein effect on retina and hippocampus of diabetic mice. Free Radic Biol Med 41, 979-984.

18. Miranda M, Muriach M, Roma J, Bosch-Morell F, Genoves JM, Barcia J, Araiz J, Diaz-Llospis M \& Romero FJ (2006) Oxidative stress in a model of experimental diabetic retinopathy: the utility of peroxinytrite scavengers (article in Spanish). Arch Soc Esp Oftalmol 81, 27-32.

19. Khachik F, de Moura FF, Zhao DY, Aebischer CP \& Bernstein PS (2002) Transformations of selected carotenoids in plasma, liver, and ocular tissues of humans and in nonprimate animal models. Invest Ophthalmol Vis Sci 43, 3383-3392.

20. Cantrell A, McGarvey DJ, Truscott TG, Rancan F \& Bohm F (2003) Singlet oxygen quenching by dietary carotenoids in a model membrane environment. Arch Biochem Biophys 412, 47-54.

21. Heber D \& Lu QY (2002) Overview of mechanisms of action of lycopene. Exp Biol Med (Maywood) 227, 920-923.

22. Chesnokova NB, Grigor'ev AV, Kuznetsova TP, Davydova NG, Olfer'ev AM, Kost OA, Nikol'skaia K II \& apitanov AB (2000) Experimental validation of licopin-containing drug tomatol use in combined therapy of patients with diabetic retinopathy (article in Russian). Vestn Oftalmol 116, 31-34.

23. Rissanen TH, Voutilainen S, Nyyssonen K, Salonen R, Kaplan GA \& Salonen JT (2003) Serum lycopene concentrations and carotid atherosclerosis: the Kuopio Ischaemic Heart Disease Risk Factor Study. Am J Clin Nutr 77, 133-138.

24. Neyestani TR, Shariatzadeh N, Gharavi A, Kalayi A \& Khalaji N (2007) Physiological dose of lycopene suppressed oxidative stress and enhanced serum levels of immunoglobulin Min patients with type 2 diabetes mellitus: a possible role in the prevention of long-term complications. $J$ Endocrinol Invest 30, 833-838.

25. Granado F, Olmedilla B, Gil-Martinez E, Blanco I, Millan I \& Rojas-Hidalgo E (1998) Carotenoids, retinol and tocopherols in patients with insulin-dependent diabetes mellitus and their immediate relatives. Clin Sci (Lond) 94, 189-195.

26. Gerster H (1997) Vitamin A - functions, dietary requirements and safety in humans. Int J Vitam Nutr Res 67, 71-90.

27. Thurnham DI \& Northrop-Clewes CA (1999) Optimal nutrition: vitamin A and the carotenoids. Proc Nutr Soc 58, 449-457.

28. Piscator M (1991) Early detection of tubular dysfunction. Kidney Int Suppl 34, S15-S17.

29. Siegenthaler G (1996) Extra-and intracellular transport of retinoids: a reappraisal. Horm Res 45, 122-127.

30. Basu TK \& Basualdo C (1997) Vitamin A homeostasis and diabetes mellitus. Nutrition 13, 804-806.

31. Tyssandier V, Choubert G, Grolier P \& Borel P (2002) Carotenoids, mostly the xanthophylls, exchange between plasma lipoproteins. Int J Vitam Nutr Res 72, 300-308.

32. During A, Dawson HD \& Harrison EH (2005) Carotenoid transport is decreased and expression of the lipid transporters SR-BI, NPC1L1, and ABCA1 is downregulated in Caco-2 cells treated with ezetimibe. J Nutr 135, 2305-2312.

33. During A, Hussain MM, Morel DW \& Harrison EH (2002) Carotenoid uptake and secretion by $\mathrm{CaCo}-2$ cells: $\beta$-carotene isomer selectivity and carotenoid interactions. J Lipid Res $\mathbf{4 3}$, $1086-1095$.

34. Van het Hof KH, West CE, Weststrate JA \& Hautvast JGAJ (2000) Dietary factors that affect the bioavailability of carotenoids. J Nutr 130, 503-506.

35. Granado-Lorencio F, Olmedilla-Alonso B, Blanco-Navarro I, Botella-Romero F \& Simal-Antón A (2006) Assessment of carotenoid status and the relation to glycaemic control in type I diabetics: a follow-up study. Eur J Clin Nutr 60, 1000-1008.

36. Watanabe S, Zhuo XG \& Kimira M (2004) Food safety and epidemiology: new database of functional food factors. Biofactors 22, 213-219.

37. Wang L, Liu S, Pradhan AD, Manson JE, Buring JE, Gaziano JM \& Sesso HD (2006) Plasma lycopene, other carotenoids, and the risk of type 2 diabetes in women. Am J Epidemiol 164, 576-585.

38. Hozawa A, Jacobs DR Jr, Steffes MW, Gross MD, Steffen LM \& Lee DH (2006) Associations of serum carotenoid concentrations with the development of diabetes and with insulin concentration: interaction with smoking: the Coronary Artery Risk Development in Young Adults (CARDIA) Study. Am J Epidemiol 163, 929-937.

39. Quilliot D, Walters E, Bonte JP, Fruchart JC, Duriez P \& Ziegler O (2005) Diabetes mellitus worsens antioxidant status in patients with chronic pancreatitis. Am J Clin Nutr 81, $1117-1125$.

40. Sugiura M, Nakamura M, Ikoma Y, Yano M, Ogawa K, Matsumoto H, Kato M, Ohshima M \& Nagao A (2006) The homeostasis model assessment-insulin resistance index is inversely associated with serum carotenoids in non-diabetic subjects. J Epidemiol 16, 71-78.

41. Granado F, Olmedilla B \& Blanco I (2004) Carotenoid depletion in serum of young type-1 diabetics fed low-carotenoid diets. Ann Nutr Metab 48, 251-258.

42. Ylonen K, Alfthan G, Groop L, Saloranta C, Aro A \& Virtanen SM (2003) Dietary intakes and plasma concentrations of carotenoids and tocopherols in relation to glucose metabolism in subjects at high risk of type 2 diabetes: the Botnia Dietary Study. Am J Clin Nutr 77, 1434-1441.

43. Suzuki K, Ito Y, Nakamura S, Ochiai J \& Aoki K (2002) Relationship between serum carotenoids and hyperglycemia: a population-based cross-sectional study. J Epidemiol 12, 357-366.

44. Upritchard JE, Sutherland WH \& Mann JI (2000) Effect of supplementation with tomato juice, vitamin $\mathrm{E}$, and vitamin $\mathrm{C}$ on LDL oxidation and products of inflammatory activity in type 2 diabetes. Diabetes Care 23, 733-738. 
45. Polidori MC, Mecocci P, Stahl W, Parente B, Cecchetti R, Cherubini A, Cao P, Sies H \& Senin U (2000) Plasma levels of lipophilic antioxidants in very old patients with type 2 diabetes. Diabetes Metab Res Rev 16, 15-19.

46. Facchini FS, Humphreys MH, DoNascimento CA, Abbasi F \& Reaven GM (2000) Relation between insulin resistance and plasma concentrations of lipid hydroperoxides, carotenoids, and tocopherols. Am J Clin Nutr 72, 776-779.

47. Levy Y, Zaltsberg H, Ben-Amotz A, Kanter Y \& Aviram M (2000) Dietary supplementation of a natural isomer mixture of $\beta$-carotene inhibits oxidation of LDL derived from patients with diabetes mellitus. Ann Nutr Metab 44, 54-60.

48. Abahusain MA, Wright J, Dickerson JW \& de Vol EB (1999) Retinol, $\alpha$-tocopherol and carotenoids in diabetes. Eur J Clin Nutr 53, 630-635.

49. Anderson JW, Gowri MS, Turner J, Nichols L, Diwadkar VA, Chow CK \& Oeltgen PR (1999) Antioxidant supplementation effects on low-density lipoprotein oxidation for individuals with type 2 diabetes mellitus. $J$ Am Coll Nutr 18, 451-461.
50. Reunanen A, Knekt P, Aaran RK \& Aromaa A (1998) Serum antioxidants and risk of non-insulin dependent diabetes mellitus. Eur J Clin Nutr 52, 89-93.

51. Olmedilla B, Granado F, Gil-Martinez E, Blanco I \& Rojas-Hidalgo E (1997) Reference values for retinol, tocopherol, and main carotenoids in serum of control and insulindependent diabetic Spanish subjects. Clin Chem 43, 1066-1071.

52. Krill D, O'Leary L, Koehler AN, Kramer MK, Warty V, Wagner MA \& Dorman JS (1997) Association of retinol binding protein in multiple-case families with insulin-dependent diabetes. Hum Biol 69, 89-96.

53. Rock CL, Jahnke MG, Gorenflo DW, Swartz RD \& Messana JM (1997) Racial group differences in plasma concentrations of antioxidant vitamins and carotenoids in hemodialysis patients. Am J Clin Nutr 65, 844-850.

54. O'Brien SF, Watts GF, Powrie JK, Shaw KM \& Miller NJ (1996) Lipids, lipoproteins, antioxidants and glomerular and tubular dysfunction in type 1 diabetes. Diabetes Res Clin Pract 32, 81-90. 